\title{
REIMBURSEMENT OF EXECUTIVES FOR CRIMINAL LITIGATION EXPENSES *
}

Executrves may be defendants in expensive litigation arising out of their activities on the corporate behalf. ${ }^{1}$ Directors and stockholders are often involved in shareholders' suits, antitrust cases, and other actions based on state and federal law. ${ }^{2}$ While they are represented by the corporation counsel in many instances, ${ }^{3}$ executives retain their own attorneys in others, ${ }^{4}$ and look to the corporate treasury for reimbursement." Indemnity for such legal expenses is often provided for in the by-laws, ${ }^{6}$ and occasionally by the employment contract. ${ }^{7}$ And there is also a common law right to reimbursement in some states. ${ }^{8}$ However, when some courts not only restricted the common

* Schwarz v. General Aniline \& Film Corp., 305 N.Y. 395, 113 N.E.2d 533 (1953).

1. The cost of litigating complex issues is sometimes astoundingly high. Duncan, The "Big Case"-IVhen Tricd Criminally, 4 W. REs. L. KEx. 99, 109 n.31 (1953); Hornstein, Directors' Expouses In Stockholders' Suits, 43 CoL L. Rw. 301, 312 (1943). Thus defense of one shareholder's suit cost dircetors \$\$6,000. Wasmisioro:, Cunkinvis Execumves' Cosipexsation 341 (1942). And some atturneys demand slodu par day as their trial fee to defend executives against antitrust clarges. Erief fur Appsllant, 11. 3, Schwarz v. General Aniline \& Film Corp., 305 N.Y. 395, 113 N.E.2d 533 (1953).

2. While the number of stockholders' suits has diminished in sume states, Hornist:in. New Aspects of Stockholders' Dericative Suits, 47 CuL L. Kcr. 1, 12 n.61 (1947), Government prosecutions involving officials of corporations are numierous. There were 1045 executives indicted for criminal antitrust violations from 1945 to Septemb3r, 1953. Figures compiled from $\mathrm{CCH}$ TRADE REg. Rep. for the years 1945-1953. During the same period, 557 officers and directors were prosecuted under the Fcderal Fuod, Drug, and Cosmetic Act. Figures compiled from U.S. Food \& Deto Amsu:istumitu:, Notres of JUDGMENT.

Executives may also run afoul of state antitrust laws, c.g., N.Y. Ge:. Bu's. Law $\S \S 340-7$ (McKinney, 1941) ; Mass. ANN. Laws c. 93, § 2 (1946), and sccurity regulation statutes, e.g., CAL. CoRp. CoDE $\$ \S 25500-15$ (Deering, 1952) ; Kr. Rev. Srar. c. 292, $\S 292.040$ (1953).

3. Twelve of fifteen corporations replying to a questionnaire follow this practice. Occasionally the defendants will retain the corporation's lawyer at their own expense. Communications to the YALE LAw JouRNaL in Yale Law Library.

4. See, e.g., United States v. Baugh \& Sons, CCH Tanus Rec. REs. I 67,507 (ED. $\mathrm{Pa} .1953$ ) ; United States v. Minneapolis Electrical Contractors Ass'n, CCH Trun= Rrec. REp. If 67,48S (D. Minn. 1953) ; United States v. National City Lines, Inc., 186 I:.2d 562 (7th Cir. 1951).

5. When individual counsel is employed, an effort is usually made in advance to secure indemnity. Communication to the YaLE LAw Jovrsal from V. Henry Rothschild, 2d, dated September 25, 1953, in Yale Law Library. Mr. Rothschild is co-author of the treatise cited infra note 34 .

6. Ibid.

7. See, e.g., Mooney v. Willys-Overland Motors, Inc, 204 F.2d 888 (3d Cir. 1953).

8. See, e.g., In re E. C. Warner Co., 232 MIinn. 207, 45 N.W.2d 383 (1950) (executive vindicated on merits in stochholder's suit); Solimine v. Hollander, 129 1.J. Eq. 264, 19 A.2d 344 (Ch. 1941) (same); Figge v. Bergenthal, 130 Wisc. 54t, 169 X.W. 581 
law right, ${ }^{9}$ but also cast doubt on the validity of by-law provisions, ${ }^{10}$ legislatures in sixteen states passed indemnity statutes to protect corporate officers. ${ }^{11}$

The New York statute is typical in providing for reimbursement in "any action, suit or proceeding"12 except where the parties are adjudged liable for misconduct or negligence. ${ }^{13}$ However, while most statutes simply state that the corporation shall, subject to similar restrictions, ${ }^{14}$ have the power to indemnify, ${ }^{15}$ the New York statute also specifically provides for court-ordered reimbursement. ${ }^{16}$ There, an executive has a statutory cause of action to recover his expenses where his company is unwilling to reimburse. ${ }^{17}$

(1906), rehearing denied, 130 Wisc. 626, 110 N.W. 798 (1907) (same). For a thorough analysis of these and other cases see WASHINGton, Corporate ExEcutives' Conirensation 334-55; 29 Chi-Kent Rev. 344 (1951) ; 26 Notre Dame Law. 540 (1951).

9. See, e.g., New York Dock Co. v. McCollom, 173 Misc. 106, 16 N.Y.S.2d 844 (Sup. Ct. 1939) (recovery of expenses by director only if a substantial benefit accrtes to the corporation as a result of his defense) ; Griesse v. Lang, 37 Ohio App. 553, 175 N.E. 222 (1931) (same).

10. Several commentators drew this conclusion from the McCollom case, supra note 9. See, e.g., Ballantine, California's 1943 Statute as to Dircctors' Litigation Expcnses: An Exclusive Remedy for Indemnification of Directors, Officers, and Employecs, 31 Calif. L. Rev. 515, 516 (1943) ; Bates \& Zuckert, Dircetors' Indemnity: Corporatc Palicy Or Public Policy?, 20 Harv. Bus. Rev. 244, 246 (1942).

11. Cal. Corp. Code $\$ 830$ (Deering, 1952); Conn. Gen. Stat. $\$ 5129$ (1949); Del. Corp. Law ANn. § 2(10) (1949) ; Ky. Rev. Stat. c. 271, § 271.375 (1953); ME. Rev. Stat. c. 49, § 23 (1944); Md. Code Ann. art. 23, §60 (Flack, 1951) ; Mich. Stat. Ann. § 21.10 (Supp. 1951); Mrnn. Stat. ANiv. § 301.09 (7) (Supp. 1952); Mo. Rev. Stat. Ann. § 351.355 (1949) ; Mont. Rev. Codes Ann. tit. 15, § 412 (1947) ; Nev. Conu. Laws $\S 1608$ (6) (Supp. 1943-9); N.J. Stat. Ans. tit. 14, § 3-14 (Supp. 1952); N.Y. GeN. Corp. Law \$§63-8 (McKinney, Supp. 1953) ; Penna. Stat. Ann. tit. 12, §1323 (Purdon, 1953) ; R.I. Acts 1948, c. 2154, p. 517; Wisc. Stat. Ann. § 180.04(14) (1951).

12. N.Y. GeN. Corp. Law $\$ \$ 63-4$ (McKinney, Supp. 1953). Other states employing the same language are: Connecticut, Delaware, Maine, Maryland, Michigan, Minnesota, Missouri, Montana, New Jersey, Nevada, and Wisconsin.

California's statute applies to "any proceeding ... whether brought by a corporation, receiver, trustee, shareholders, governmental body, public official. . . ." Rhode Island's statute indemnifies officers and directors against "all claims and liabilities." Kentucky's wording is "any action." Pennsylvania awards reimbursement in "any suit brought to enforce a secondary right of stockholders." See statutes cited note 11 silpra.

13. Twelve state statutes follow the New York wording in this respect: Connecticut, Delaware, Kentucky, Maine, Maryland, Michigan, Minnesota, Missouri, Montana, Nevada, Rhode Island, and Wisconsin. California, New Jersey, and Pennsylvania have slightly different provisions. Statutes cited supra note 11.

14. See note 13 supra.

15. These include: Delaware, Kentucky, Maryland, Michigan, Minnesota, Missouri, Montana, New Jersey, Nevada, and Wisconsin. Connecticut and Rhode Island specify that a corporation may permit indemnification in the by-laws. Maine and New York state that a corporation may permit indemnification in the certificate of incorporation, in the by-laws, or by resolution in specific situations. Statutes cited supra note 11.

16. N.Y. Gen. Corp. Law \$ 64 (McKinney, Supp. 1953). California and Pennsylvania alone have similar provisions. See note 11 supra.

17. Directors have recovered expenses in civil litigation under this provision. Sec, 
In the recent case of Schwarz v. Gencral Aniline \& Film Corp., ${ }^{18}$ an attempt was made for the first time to use the statutory court-ordered reimbursement provision to recover the costs of defending a criminal action. Schwarz, an officer and director of General Aniline, had been indicted for violation of the antitrust laws. ${ }^{19}$ He pleaded nolo contendere and was fined $\$ 500 .^{20}$ After the corporation refused to indemnify him for his $\$ 7,500$ legal expense, or for the fine, Schwarz sued in the New York courts to recover his loss. The trial court denied recovery on the ground that his plea of nolo constituted an adjudication of misconduct, barring relief by the terms of the statute. ${ }^{21}$ The Appellate Division affirmed without opinion. ${ }^{22}$ In the New York Court of Appeals three dissenting judges disagreed.23 However, the majority, consisting of four judges, did not consider this question, but denied relief on the broad ground that the legislature had not intended to include the costs of defending a criminal action under the court-ordered reimbursement provision. ${ }^{24}$ Under this view a defendant could not recover his expenses even if he were acquitted after trial.

Although Schaiarz clearly bars court-ordered reimbursement in criminal cases, it apparently does not threaten the legality of indemnity paid voluntarily by the company. A concurring judge, who cast the deciding vote for the majority view, expressly approved reimbursement for criminal expenses by provision in the articles of incorporation or by-laws, or by resolution of the shareholders. ${ }^{25}$ Since most other statutes provide only that the corporation

e.g., Diamond v. Diamond, 200 Misc. 1074, 108 N.Y.S.2d $\$ 64$ (Sup. Ct. 1951), aff'd, 281 App. Div. 1015, 121 N.Y.S.2d $2 S 0$ (1st Dep't 1953) ; Dornan v. Humphrey, 278 App. Div. 1010, 106 N.Y.S.2d 142 (4th Dep't 1951), rehearing deried, 110 N.Y.S.2d 471 (4th Dep't 1952) ; Tichner v. Andrews, 193 Misc. 1050, 85 N.Y.S.2d 760 (Sup. Ct. 1949).

18. 305 N.Y. 395, 113 N.E.2d 533 (1953).

19. Defendants were charged with conspiring to restrain trade by forming an illegal cartel in photographic materials in violation of Section 1 of the Sherman Act. Indictment No. 111-136, filed on December 19, 1941 in the District Court of the United States for the Southern District of New York.

20. Schwarz tried unsuccessfully to recover his litigation expenses in federal court. His petition was dismissed on jurisdictional grounds. Petition of Schwarz, 94 F. Supp. 129 (1950).

21. Schwarz v. General Aniline \& Film Corp., 198 Mfise 1046, 102 N.Y.S.2d 325 (Sup. Ct. 1951).

22. Schwarz v. General Aniline \& Film Corp., 279 App. Div. 996,112 X.Y.S2d 146 (1st Dep't 1952). Judge Van Voorhis, dissenting, argued that a plea of nolo was nut an adjudication of misconduct. Id. at 996, 997-8, 112 N.Y.S.2d at 147, 148-50.

23. Schwarz v. General Aniline \& Film Corp., 305 N.Y. 395, 407, 113 X.E.2d 533, 538 (1953).

24. Id. at 400,113 N.E.2d at 535.

25. Id. at 405,113 N.E.2d at 537. Recent changes in the personnel of the Court indicate that Schi'arz will not be extended. Judge Carswell, who cast the crucial vote, died shortly after his concurring opinion was filed. Judge Van Voorhis, who voted for recovery when the principal case was in the Appellate Division, now sits on the Cuurt of Appeals. N.Y. Times, April 24, 1953, p. 35, col. 1. 
may reimburse, ${ }^{26}$ the Court of Appeals' holding should not influence voluntary payment of criminal litigation expenses in these states. And of the two states besides New York that make statutory provision for court-ordered indemnity, one by its terms excludes, ${ }^{27}$ while the other apparently allows, ${ }^{28}$ recovery of the kind denied by the New York court. Thus, since prevalent corporate practice is the voluntary reimbursement of executives on by-law authority for expenses incurred in either civil or criminal cases, ${ }^{20}$ Schrvarz' effect may be limited.

The dichotomy between permitting voluntary indemnification and disallowing court-ordered reimbursement seems anomalous. Schwarz does violence to the aim of the New York legislature, which redrafted the reimbursement statutes in 1945 in an effort to make "consistent" the provisions for courtordered and voluntary reimbursement. ${ }^{30}$ If the New York court reasoned correctly that the legislature did not intend the words "any action, suit or proceeding" to cover criminal suit expenses in the court-ordered reimbursement section of the statute, it becomes difficult to argue that the legislature intended an opposite meaning by the same words in the by-law authorization section. Moreover, the legislative purpose of protecting directors ${ }^{31}$ seems thwarted by dismissing without remedy an official who cannot secure reimbursement under permissive corporate by-laws because, as in Schwar, he is a member of a faction no longer in control. ${ }^{32}$ Some courts, unwilling to justify different standards for court-ordered and voluntary reimbursement,

26. The statutory provisions are cited in note 15 supra. For a similar view sec Comment, 40 CALIF. L. REv. 104, 111 (1952).

27. The Pennsylvania statute applies by its terms only to expenses incturred in stockholders' derivative suits. Penna. Stat. Ann. tit. 12, $\$ 1323$ (Purdon, 1953).

28. The California statute permits recovery of expenses incurred in any suit brought "by a corporation ... shareholders, governmental body. . . ." CAL. CORP. CODE $\$ 830$ (Deering, 1952) (emphasis added). For a discussion of the California statute see Ballantine, California's 1943 Statute as to Directors' Litigation Expenses: An Exclusive Remedy for Indemnification of Directors, Officers, and Employees, 31 CALIF. L. REv. 515 (1943).

29. See source cited note 5 supra.

30. The former New York statutory provision for court-ordered reimbursement restricted indemnity for expenses to those incurred in any action "brought by the corporation or brought in its behalf." N.Y. LAws 1941, c. 350, § 61-a. The 1945 revision changed this language to cover "any action, suit or proceeding." N.Y. GEN. CoRP. LAw § 64. This had always been the language of the by-law authorization section of the New York statute. N.Y. Laws 1941 , c. $209, \S 27-a$. The change in wording was a studied effort toward consistency. N.Y. Law Revision Comm., Recommendation AND Study ReLATing to Retmbursement of Litigation Expenses of Corporate Officials 131, 139 (1945).

31. 75 Ass'n of the Bar of the City of New York, Comm. on State Legislation rep. no. 188, p. 513 (1941) ; New York State Bar Ass'n, Comm. on State LeasLAtion rep. no. 9, p. 27 (1941); Hornstein, supra note 1, at 301; Note, 37 Corneul L.Q. 78, 84 (1951).

32. Schwarz v. General Aniline \& Film Corp., 305 N.Y. 395, 398, 113 N.E.2d 533 (1953). 
may extend Schwwarz to bar even voluntary reimbursement under statutory authority.

However, courts have been traditionally more willing to sustain reimbursement once paid, than to order an unwilling corporation to indemnify.33 Stockholders attacking the legality of payments to executives must overcome the rule that an exercise of business judgment by directors will nit be overturned except in cases approaching fraud. ${ }^{34}$ And where stockholders have ratified the payment or the by-law under which payment is authorized, dissenters have an even heavier burden of proof. ${ }^{35}$ Thus, upon a finding that all the parties acted in good faith, a New York court has allowed a corporation to finance voluntarily the defense of executives in a criminal action, even though they were adjudged guilty of violating the Sherman Act. ${ }^{30}$ In effect, Schra'arz, narrowly read, makes reimbursement of criminal litigation expenses a matter of business discretion, in which the court is generally unwilling to substitute its judgment for that of directors and shareholders.

Even if Schw'arz is treated broadly by other courts to bar any criminal case reimbursement under indemnity statutes, executives may have a common law right to recovery in some states. ${ }^{37}$ One line of cases permits recovery where the executive defended a vital corporate interest. ${ }^{39}$ On this reasoning, executives have recovered their expenses when they opposed minority stockholders' attempts to throw the company into receivership ${ }^{39}$ or to upset a re-

33. Compare Simon v. Socony-Vacuum Oil Co., 179 Afisc. 202, 39 X.Y.S.2d 270 (Sup. Ct. 1942), aff'd mem., 267 App. Div. 890, 47 N.Y.S.2d 589 (1st Dep't 1944) (court refused to upset corporate outlays for executives), and Blish v. Thompson Automatic Arms Corp., 30 Del. Ch. 538, 64 A.2d 581 (Sup. Ct. 194S) (same), aih New York Dock Co. v. McCollom, 173 Misc 106, 16 N.Y.S.2d $\$ 44$ (Sup. Ct. 1939) (court refused to compel corporation to reimburse directors), and Hoch v. Duluth Brewing \& Malting Co., 173 Minn. 374, 217 N.W. 503 (1928) (same).

34. For statements of this "proper business judgment rule," see Clanitz v. Thateher Mffg. Co., 158 F.2d 687, 693 (2d Cir.), cert. denied, 331 U.S. \$25 (1947); Diamond v. Davis, 38 N.Y.S.2d 103, 115 (Sup. Ct. 1942), aff'd mem., 292 N.Y. 554, 54 N.E.2d 6.3 (1944). And see cases and discussion in Wasmington \& Rormscailn, Cosfe:isatioto The CoRporate Executtve 383-412 (1951).

35. See, e.g., Continental Securities Co. v. Belmont, 206 N.Y. 7, 17-18, 99 X.E. 138, 142 (1912). For collection of cases see Washington \& RoThscurn, op. cil. supra note 34 , at $252-5$.

36. Simon v. Socony-Vacuum Oil Co., 179 גiisc. 202, 38 N.Y.S.2d 270 (Sup. Ct. 1942), aff'd menn., 267 App. Div. S90, 47 N.Y.S.2d 589 (1st Dep't 1944). For a similar good faith theory see Kanneberg v. Evangelical Creed Corp., 146 Wisc. 610, 131 N.W. 353 (1911).

37. See note $S$ supra. For a recent judicial view that common law recovery is being liberalized, see Mooney v. Willys-Overland Motors, Inc, 204 F.2d SSS, 899 (3d Cir. 1953).

38. See, e.g., Albrecht, Maguire \& Co. v. General Plastics, Inc, 256 App. Div. 134, 139, 9 N.Y.S.2d 415, 420 (4th Dep't), aff'd, 280 N.Y. 840, 21 N.E.2d $8 S 7$ (1039); Esposito v. Riverside Sand \& Gravel Co., 287 Miass. 185, 187, 191 N.E. 363, 364 (1934).

39. Godley v. Crandall \& Godley Co., 181 App. Div. 75, 7\&, 168 N.Y.Supp. 251, 254 (1st Dep't 1917), aff'd, 227 N.Y. 656, 126 N.E. 908 (1920). 
organization plan..$^{40}$ Defending a corporate business practice in a criminal antitrust attack may be similarly treated. But courts have sometimes denied common law recovery on the ground that the expenses did not flow directly from performance of official duties, but resulted from alleged personal misconduct. ${ }^{41}$ Since the line between defense of a corporate interest and alleged personal misconduct is sometimes thin, ${ }^{42}$ directors would be ill-advised to rest on their common law rights.

In view of the present uncertainty regarding executive reimbursement rights, corporate officials would do well to secure employment contracts that specifically provide for recovery of criminal litigation expenses. Such added protection would hedge against the possibility that Schwarz may be extended to bar by-law recovery. Even if the New York case is limited to its facts, a particular corporation may have no by-law provisions or may be unwilling to reimburse under permissive by-laws. And though a corporation wants to reimburse, it may doubt its power to do so when its by-laws make no specific reference to criminal cases. The additional protection afforded by contract is indirectly sanctioned by many reimbursement laws, which expressly provide that the statutory authority is not exclusive. ${ }^{43}$ Interpreting such a provision in the Delaware statute, a recent Third Circuit case held that a director could recover his expenses in defending a shareholder's suit, on the independent theory that his contract with the corporation provided for such indemnity. ${ }^{44}$ Thus a carefully worded contract might insure recovery

40. Corey v. Independent Ice Co., 226 Mass. 391, 395, 115 N.E. 488, 490 (1917).

41. See, e.g., Hoch v. Duluth Brewing \& Malting Co., 173 Minn. 374, 217 N.W. 503 (1928) (no recovery for expenses in land fraud criminal case even though there was a successful defense on the merits); Du Puy v. Crucible Steel Co. of America, 288 Fed. 583 (W.D. Pa. 1923) (recovery denied for criminal litigation expenses in tax fratud case even though the director was successful on the merits).

42. A director accused of falsely registering securities was held to have defended a corporate interest when he defended himself. Blish v. Thompson Automatic Arms Corp., 30 Del. Ch. 538, 64 A.2d 581 (Sup. Ct. 1948). However, a director accused of filing a false tax return for the corporation was denied recovery. Du Puy v. Crucible Stecl Co. of America, 288 Fed. 583 (W.D. Pa. 1923).

43. See, e.g., Connecticut, Delaware, Maine, Maryland, Minnesota, Nevada, and Wisconsin (statutes not exclusive of other rights under any statute, by-law, agreement, vote of stockholders or otherwise).

Missouri's statute provides that "the right to indemnification herein provided shall not be exclusive of any other rights to which such director or officer may be lawfully entitled." In New Jersey, the statutory remedy is "in addition to and not in restriction or limitation of any other privilege or power which a corporation of this State may have with respect to the indemnification or reimbursement of directors, trustces, officers or employees." New York's statute says that "such right of indemnification shall not be deemed exclusive of any other rights to which such director, officer or employee may be entitled apart from this statute." Rhode Island's provision "shall not be deemed to exclude any other right or privileges to which such person may be entitled." Statutes cited note 11 supra.

44. "Where there exists, as there does here, an independent ground for the payment of litigation expenses [the contract], we see no reason to make an overriding reference 
of criminal case expenses even where reimbursement is in doubt on common law, by-law, or statutory theories.

Certain restrictions on the use of employment contract indemnification are necessary to prevent unjustified claims for reimbursement. Courts will probably not enforce such clauses unless they were bargained-for, provide for reimbursement of only reasonable expenses, and result in some benefit to the corporation. ${ }^{45}$ Such a benefit may be the executive's remaining in corporate employ ${ }^{46}$ or his incentive to do better work because of the added security afforded by the clause. ${ }^{47}$ Where the executive is alrealy obligated to serve for a period, or where he shares in other incentive devices, granting reimbursement rights may be called an illegal gift of corporate funds. ${ }^{2 s}$ But an amendment to the contract should be upheld if the director agrees to perform added tasks or to serve for a longer term than originally fixed in return for his reimbursement clause. ${ }^{49}$ In addition to the requirement that indemnity clauses be supported by consideration, courts should prohibit reimbursemtnt of criminal litigation expenses where the executive was adjudged lialle for negligence or misconduct. Such a standard is required by almust all indemnification statutes ${ }^{50}$ and by the cases permitting common law recovery, and will probably also govern contractual reimbursement. ${ }^{51}$ What constitutes negligence or misconduct is an issue made irrelevant by Schziars' broad theory prohibiting court-ordered reimbursement of any criminal litigation expenses. Such an issue will become crucial if Schu'urz can be circumrented by contractual provisions.

to the statute." Mooney v. Willys-Overland Motors, Ine, 304 F.2d $8 \mathrm{x}, 89 \mathrm{u}(3 \mathrm{~d}$ Cir. 1953). Although Mooncy dealt with civil litigation expenses, it sccms dubtiul that a contract providing for reimbursement of criminal case expenses would the treated differently. See Schwarz v. General Aniline \& Film Corp., 305 N.Y. 395, 405, 113 X.E. 21 333, 537 (1953) (concurring opinion).

45. A corporation may contract to reimburse a director in exchange for resignation before the term of his employment contract has expired. "Out of the context of a termination agreement, all of these payments might be ultra vircs as mere gifts." Mlouney v. Willys-Overland Motors, Inc., 204 F.2d SSS, 895 (3d Cir. 1953).

46. See, e.g., Sandler v. Schenley Industries, Inc, - Del. Ch. -, 79 A.2d 606, 609 (Ch. 1951) (employment contract justifies stock option) ; Holthusen v. Budd IIf. Co., 53 F. Supp. 488, 490 (E.D. Pa. 1943) (same).

47. Cf. Gottlieb v. Heyden Chemical Corp., 22 U.S.L. WeEk 2150 (Del. Ch. Octubar 8 , 1953) (increased incentives held good consideration for executive compensation); Eliasberg v. Standard Oil Co., 23 N.J. Super. 431 (1952) (same).

48. For analysis of the legal problems involved in amending contracts see WAsHLicTON \& RoTHSCHID, op. cit. supra note 34, at 269-71 and cases cited therein.

49. Ibid.

50. See note 13 supra.

51. One court has indicated that the statutory standard sets "realistic limits" on the right of indemnification. Sce Mooney v. Willys-Overland MIotors, Inc, 204 F.2d 889 , 896 (3d Cir. 1953). 